\title{
Bovine tuberculosis in Rwanda: Prevalence and economic impact evaluation by meat inspection at Société des Abattoirs de Nyabugogo-Nyabugogo Abattoir, Kigali
}

\begin{tabular}{|c|c|}
\hline \multicolumn{2}{|c|}{$\begin{array}{l}\text { Authors: } \\
\text { Gervais Habarugira }^{1} \\
\text { Joseph Rukelibuga }^{2} \\
\text { Mark O. Nanyingi,4 }^{3,4} \\
\text { Borden Mushonga }^{5}\end{array}$} \\
\hline $\begin{array}{l}\text { Affiliations: } \\
{ }^{1} \text { School of Anir } \\
\text { and Veterinary } \\
\text { University of R }\end{array}$ & $\begin{array}{l}\text { Mal Sciences } \\
\text { Medicine, } \\
\text { vanda, Rwanda }\end{array}$ \\
\hline $\begin{array}{l}{ }^{2} \text { United States } \\
\text { for Disease Co } \\
\text { Prevention, Kig }\end{array}$ & $\begin{array}{l}\text { Centers } \\
\text { trol and } \\
\text { ali, Rwanda }\end{array}$ \\
\hline $\begin{array}{l}{ }^{3} \text { Department } 0 \\
\text { Pharmacology } \\
\text { University of } \mathrm{N}\end{array}$ & $\begin{array}{l}\text { Public Health, } \\
\text { and Toxicology, } \\
\text { airobi, Kenya }\end{array}$ \\
\hline $\begin{array}{l}{ }^{4} \text { Kenya Medica } \\
\text { Institute, Unite } \\
\text { Centers for Dis } \\
\text { and Preventior }\end{array}$ & $\begin{array}{l}\text { Research } \\
\text { d States } \\
\text { ease Control } \\
\text { Kenya }\end{array}$ \\
\hline $\begin{array}{l}{ }^{5} \text { Department } \\
\text { Pasture Scienc } \\
\text { Fort Hare, Sou }\end{array}$ & $\begin{array}{l}\text { Livestock and } \\
\text { University of } \\
\text { h Africa }\end{array}$ \\
\hline $\begin{array}{l}\text { Corresponden } \\
\text { Gervais Habar }\end{array}$ & $\begin{array}{l}\text { e to: } \\
\text { gira }\end{array}$ \\
\hline $\begin{array}{l}\text { Email: } \\
\text { gervaish@gma }\end{array}$ & I.com \\
\hline $\begin{array}{l}\text { Postal address } \\
\text { PO Box 57, Ny }\end{array}$ & gatare, Rwanda \\
\hline $\begin{array}{l}\text { Dates: } \\
\text { Received: } 06 \mathrm{Ju} \\
\text { Accepted: } 11 \mathrm{~N} \\
\text { Published: } 05 \mathrm{I} \\
\text { Republished: } 1\end{array}$ & $\begin{array}{l}\text { ne } 2013 \\
\text { lar. } 2014 \\
\text { lov. } 2014 \\
7 \text { Nov. } 2014\end{array}$ \\
\hline $\begin{array}{l}\text { How to cite th } \\
\text { Habarugira, G. } \\
\text { Nanyingi, M.O } \\
\text { B., 2014, 'Bovir } \\
\text { in Rwanda: Pre } \\
\text { economic imp } \\
\text { by meat inspe } \\
\text { des Abattoirs o } \\
\text { Nyabugogo Ab } \\
\text { Journal of the } \\
\text { Veterinary Ass } \\
\text { Art. \#1062, } 5 \text { p } \\
\text { dx.doi.org/10. } \\
\text { v851i1.1062 }\end{array}$ & $\begin{array}{l}\text { Rukticle: } \\
\text { Rukelibuga, J., } \\
\text { \& Mushonga, } \\
\text { e tuberculosis } \\
\text { valence and } \\
\text { ct evaluation } \\
\text { tion at Société } \\
\text { Nyabugogo- } \\
\text { ttoir, Kigali', } \\
\text { outh African } \\
\text { ciation 85(1), } \\
\text { ges. http:// } \\
\text { 102/jsava. }\end{array}$ \\
\hline 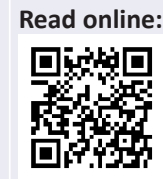 & $\begin{array}{l}\text { Scan this QR } \\
\text { code with your } \\
\text { smart phone or } \\
\text { mobile device } \\
\text { to read online. }\end{array}$ \\
\hline
\end{tabular}

Authors:

Affiliations: and Veterinary Medicine,

${ }^{2}$ United States Centers for Disease Control and

Prevention, Kigali, Rwanda

University of Nairobi, Kenya

${ }^{4}$ Kenya Medical Research Institute, United States Centers for Disease Contro and Prevention, Kenya Pasture Science, University of

Correspondence to:

Email:

Postal address:

Dates:

Received: 06 June 2013

Accepted: 11 Mar. 2014

Republished: 17 Nov. 2014

How to cite this article: Habarugira, G., Rukelibuga, J., Nanyingi, M.O. \& Mushonga, B, 2014, 'Bovine tuberculosis economic impact evaluation by meat inspection at Sociéte des Abattoirs de NyabugogoNyabugogo Abattoir, Kigali', Journal of the South African Art. \#1062, 5 pages. http:// dx.doi.org/10.4102/jsava. v851i1.1062

\begin{abstract}
Despite the significant public health burden of bovine tuberculosis (bTB) in Rwanda, the prevalence of bTB is poorly documented. This study was conducted to estimate the prevalence of bTB in cattle using gross examination of granulomatous lesions, to identify mycobacteria species in suspected samples, and to evaluate the economic impact of meat condemnation based on bTB-like lesions in the meat industry in Rwanda. Routine meat inspection was conducted at Société des Abattoirs de Nyabugogo (SABAN)-Nyabugogo Abattoir. Tissue samples including 31 lymph nodes, 3 lungs and 2 livers were obtained from cattle of different ages with gross tuberculous lesions. Mycobacterium bovis was identified using microscopy with Kinyoun staining and isolation of mycobacterial species in culture on Löwenstein-Jensen and Colestos media, further identified using biochemical tests. Our findings, based on culture and postmortem results, show that the prevalence of bTB is $0.5 \%$ $\left(0.587^{*} 148 / 16753\right)$, with an overall gross tuberculous lesion prevalence of $0.9 \%(148 / 16753)$. The presence of lesions were higher in cattle aged 2 years and older $(1.6 \%$ vs. $0.6 \%, p<0.05)$ and higher in females than in males $(1.4 \%$ vs. $0.6 \%, p<0.05)$. Of the 36 samples tested, 26 $(72.2 \%)$ were positive by microscopic examination with Kinyoun staining while M. bovis was culture-confirmed in $21(58.7 \%)$ cases. Bovine tuberculosis caused condemnation of $1683.5 \mathrm{~kg}$ of meat, resulting in an estimated loss of $\$ 4810$. Our findings indicate that the prevalence of bTB in Rwanda is significant, and that bTB is a major cause of meat condemnation requiring continued implementation of surveillance and control measures. Furthermore, the results from this study also show important variations in sensitivity of the different tests that were used to determine the prevalence of bTB in cattle in Rwanda.
\end{abstract}

\section{Introduction}

Tuberculosis (TB) is an infectious and contagious disease common to human and many animal species (Ayele et al. 2004; Palmer, Waters \& Whipple 2004) and remains a major health threat to both humans and animals throughout the world (Cosivi et al. 1995, 1998; Michel 2002). For this reason, TB is both an economic and public health threat (Biet et al. 2004; Haddad \& Durand 2001; Michel et al. 2007). Laboratory diagnosis of Mycobacterium tuberculosis in humans and Mycobacterium bovis in cattle is based on biochemical identification, following isolation in culture, and molecular identification of the causative agent. However, in developing countries, bovine tuberculosis (bTB) diagnosis in cattle relies on postmortem examination by meat inspection (Shitaye et al. 2006).

In developed countries, (bTB eradication programmes based on screening and slaughtering of infected animals as well as milk pasteurisation have been successful (Cosivi et al. 1998; Franck et al. 2005).

In Rwanda, TB and bTB remains a significant public health threat, with an average of 91.3 per 100000 populations per year of new human cases (all forms) reported from 2005 through 2007 (Minisante 2007). It is estimated that $5 \%$ of the cattle population in the world react positively to a tuberculin test; that is approximately 50 million of cattle that might be infected by bTB (Chantal 2001). Moreover, cattle remain the most important source of $M$. bovis infections to humans and other animals but are also at risk as cattle can be reinfected with $M$. bovis by contact with humans (Aranaz et al. 2004; Krauss et al. 2003).

The objectives of this study were to determine the prevalence of bTB by evaluating the presence of granulomatous lesions in cattle at a Kigali abattoir, to identify different mycobacteria species

Note: This article was republished with the correct spelling of Société des Abattoirs de Nyabugogo.

Copyright: (c) 2014. The Authors. Licensee: AOSIS OpenJournals. This work is licensed under the Creative Commons Attribution License. 
that are responsible for lesions resembling tuberculosis and evaluate the economic impact of bTB on the beef industry in Rwanda.

\section{Materials and methods Geographical study area}

The study was carried out at Société des Abattoirs de Nyabugogo (SABAN)-Nyabugogo Abattoir in Kigali on slaughtered animals from four provinces, namely eastern, northern, southern and western Rwanda, and Kigali city (Table 1). Laboratory examinations were performed at the microbiological laboratory of the Higher Institute of Agriculture and Animal Husbandry (ISAE).

\section{Meat inspection and sample collection}

Routine meat inspection was performed by meat inspectors under the supervision of veterinarians from the Rwanda Agriculture Board (RAB). The study was conducted on 16753 animals slaughtered at SABAN-Nyabugogo Abattoir in Kigali, Rwanda over a period of 11 months (JanuaryNovember 2009) to estimate the prevalence of bTB by gross inspection of lesions resembling tuberculosis (Table 1). In this study, a lesion resembling bTB was defined as any grossly discernible raised lump with a diameter of $5 \mathrm{~mm}$ to $>25 \mathrm{~mm}$ showing, mostly, greyish white colour with a fluctuant or granular consistency. Bovine TB-like lesions could also be inspissated with a lamellar appearance on cut surface. An additional 36 tissue samples were obtained from the condemned organs of several animals. The samples comprised 31 lymph nodes (retropharyngeal, mediastinal and tracheobronchial), three lung samples and two liver samples. Suspected organs and tissues were dissected and inspected. Samples were collected into sterile plastic bags and placed in a cooler box with ice to maintain the cold chain and eliminate sample deterioration before transportation to the laboratory, where they were stored at $4^{\circ} \mathrm{C}$.

\section{Sample processing and laboratory examination}

Collected samples were analysed either the same day or the day following arrival at the laboratory. Microscopy with Kinyoun staining technique, culture on LöwensteinJensen and Colestos media and biochemical tests for species identification were used to confirm suspected cases of bTB.

The presence of acid-fast bacteria (AFB) was confirmed by Kinyoun staining of an impression smear made directly from a tissue sample. A positive control for Kinyoun staining was also used as previously described (Nolte \& Metchock 1995).
Stained microscopic slides were observed under microscope with objectives $\times 100$ (oil immersion objective). Samples to be cultured were prepared according to World Organisation for Animal Health (OIE) guidelines (OIE 2009). Using sterile scissors, excess fat was removed and tissue was carefully cut into small pieces to avoid incising the lesion. Cut pieces were then homogenised in a motor with sea sand and a sterile solution of sodium chloride $(\mathrm{NaCl} 0.85 \%)$. A pestle was used for grinding. The ground material was homogenised with vortex and then $7 \mathrm{~mL}$ was withdrawn and centrifuged in a test tube. An additional $5 \mathrm{~mL}$ of sodium hydroxide $(\mathrm{NaOH}) 0.5 \mathrm{~N}$ was added, and after $10 \mathrm{~min}$ the mixture was neutralised by adding a few drops of $6 \mathrm{~N}$ hydrogen chloride solution until the colour changed to yellow. The $\mathrm{pH}$ was lowered by adding a few drops of $1 \mathrm{~N}$ sodium hydroxide until the appearance changed to a pale pink colour. The suspension was then centrifuged at $3000 \mathrm{rpm}$ for $15 \mathrm{~min}$. The supernatant was discarded and the medium was inoculated with $200 \mu \mathrm{L}$ of the pellet per tube. For culturing purposes, two culture media were used: Colestos containing glycerol, which was ready to use, and Löwenstein-Jensen without glycerol, which was prepared before use. Each sample was inoculated into two test tubes containing Löwenstein-Jensen and Colestos media, respectively. After inoculation, the tubes were incubated at $37^{\circ} \mathrm{C}$ in an inclined position and unscrewed for 4 days to allow the condensation to evaporate. The incubated tubes were checked once a week. The incubation was maintained for 16 weeks. After isolation of mycobacteria, identification by biochemical tests was performed. Two tests were used, namely a urea/indole test and a catalase test.

\section{Record on meat condemnation at the abattoir}

From January to November 2009, the condemned carcasses and organs (head, liver, lungs, intestines, abomasum and kidneys) were recorded and weighed daily. The economic losses were estimated at prevailing market values.

\section{Data analysis}

Demographic and epidemiological characteristics were analysed using descriptive statistics. Categorical variables were described with the use of percentages. Bivariate analysis was performed using $\chi^{2}$ and Fischer's exact tests with $p$-values $\leq 0.05$ considered significant. Data analyses were performed using Excel and STATA 12.1.

\section{Ethical considerations}

Ethical approval for this study protocol was obtained from the Institutional Review Board of the Faculty of Veterinary

TABLE 1: Origin of slaughtered animals.

\begin{tabular}{|c|c|c|c|c|c|c|c|c|c|c|c|c|}
\hline \multirow[t]{2}{*}{ Origin } & \multicolumn{12}{|c|}{ Month } \\
\hline & Jan. & Feb. & Mar. & Apr. & May & June & July & Aug. & Sept. & Oct. & Nov. & Total \\
\hline East & 1677 & 1705 & 770 & 1030 & 1240 & 1825 & 1176 & 346 & 290 & 526 & 475 & 11060 \\
\hline North & 151 & 164 & 55 & 188 & 327 & 330 & 226 & 222 & 777 & 975 & 928 & 4343 \\
\hline South & 29 & 19 & 29 & - & 29 & 22 & 65 & 92 & 152 & 64 & 80 & 581 \\
\hline West & 19 & - & - & - & - & - & 14 & 91 & 141 & 235 & 237 & 737 \\
\hline Kigali City & 19 & - & - & - & - & - & - & - & - & 8 & 5 & 32 \\
\hline Total & 1895 & 1888 & 854 & 1218 & 1596 & 2177 & 1481 & 751 & 1360 & 1808 & 1725 & 16753 \\
\hline
\end{tabular}


Medicine, College of Agriculture and Veterinary Sciences, University of Rwanda. The sample collection was performed by a qualified veterinarian assisted by meat inspectors through routine antemortem and postmortem inspection to ensure personnel safety. Abattoir owners were informed of the study purpose and procedures and provided written consent prior to study procedures and sample collection from their animals.

\section{Results}

\section{Estimation of losses as a result of meat condemnation as a result of bovine tuberculosis}

Before suspected organs were discarded, they were weighed and the monetary loss was estimated. A total of $1683.5 \mathrm{~kg}$ of meat was condemned and the loss as a result of the presence of bTB lesions was estimated to be RWF3 030300 (\$4810). The pathomorphological examination during meat inspection showed that $148(0.9 \%)$ of the 16753 slaughtered cattle had tuberculous lesions. It was also revealed that females had higher lesion prevalence than males (1.4\% vs. $0.6 \%$, $p<0.05, n=16753)$. Cattle aged $>2$ years had higher lesion prevalence than those $<2$ years $(1.6 \%$ vs. $0.6 \%, p<0.05$, $n=16753)$. The head was the most predominant of the condemned organs, with $65(43 \%)$ condemned heads (Table 2), because of caseous necrosis lesions in the lymph nodes. This was significantly higher $(p<0.05, n=148)$ than in other organs, except the liver, which also had a higher occurrence of bTB lesions (33.8\%). A monthly trend analysis indicated that all the values recorded in the period between June and August were significantly higher $(p<0.05)$ than the rest of the year, except the month of February (Table 2).

\section{Laboratory analysis}

\section{Kinyoun staining and microscopic examination}

Of the 36 samples that were microscopically examined, 26 $(72.2 \%)$ were positive to Kinyoun staining. Amongst the 26 samples, there were 22 lymph nodes from different organs, two liver specimens and two lung specimens (Table 3).

\section{Isolation and identification}

A total of 36 samples (both negative and positive to Kinyoun staining) were cultured and mycobacteria were isolated in $23(63.9 \%)$ of them (Table 4$)$. With the exception of two samples for which colonies appeared on the 9th day, the first colonies appeared on the 24th day. Based on results of biochemical test for identification, $M$. bovis was present in $91.3 \%(n=23)$ of the samples and atypical mycobacteria in $8.7 \%(n=23)$ (Table 5).

\section{Estimating bovine tuberculosis prevalence}

AFB were microscopically recognised and confirmed in 26 (72.2\%) samples of the total 36 specimens examined by the Kinyoun staining technique. Mycobacterium bovis was only confirmed in 21 (58.7\%) samples by culture. As AFB culture is a relatively confirmatory method compared to the Kinyoun staining technique for $M$. bovis, the overall postmortem prevalence of $M$. bovis using culture was estimated to be $0.5 \%$ $\left(0.587^{*} 148 / 16753\right)$.

\section{Discussion}

Bovine TB is a chronic disease of animals caused by the bacterium $M$. bovis, which is closely related to the bacterium M. tuberculosis, the causative agent of human tuberculosis. Humans are susceptible to bTB and can be infected by both by drinking raw milk from infected cattle or by inhaling infective droplets. It is estimated in some countries that up to $10 \%$ of human tuberculosis can be ascribed to bTB (OIE 2012). Diagnosis of bTB in cattle is by the tuberculin skin test (Cosivi et al. 1998; Palmer et al. 2004), by which a small amount of antigen is injected into the skin and the immune reaction is measured. Culturing the bacteria in the laboratory for about 8 weeks is used to confirm diagnosis. This study is the first reported to describe the prevalence of bTB in cattle in Rwanda

TABLE 3: Results of Kinyoun staining.

\begin{tabular}{llll}
\hline Organ & $\begin{array}{l}\text { Number of } \\
\text { samples }\end{array}$ & $\begin{array}{l}\text { Kinyoun } \\
\text { positive }\end{array}$ & Percentage (\%) \\
\hline Lymph nodes & 31 & 22 & 70.8 \\
Lungs & 3 & 2 & 66.6 \\
Liver & 2 & 2 & 100 \\
\hline Total & $\mathbf{3 6}$ & $\mathbf{2 6}$ & $\mathbf{7 2 . 2}$ \\
\hline
\end{tabular}

TABLE 4: Positive cultures from samples.

\begin{tabular}{lllll}
\hline Kinyoun & $\begin{array}{l}\text { Negative } \\
\text { cultures }\end{array}$ & $\begin{array}{l}\text { Positive } \\
\text { cultures }\end{array}$ & Total & $\begin{array}{l}\text { Percentage } \\
(\%)\end{array}$ \\
\hline Kinyoun (-) & 8 & 2 & 10 & 27.8 \\
Kinyoun (+) & 5 & 21 & 26 & 72.2 \\
\hline Total & 13 & $\mathbf{2 3}$ & $\mathbf{3 6}$ & $\mathbf{1 0 0}$ \\
Percentage (\%) & $\mathbf{3 6 . 1}$ & $\mathbf{6 3 . 9}$ & $\mathbf{1 0 0}$ & - \\
\hline
\end{tabular}

TABLE 2: Condemned organs according to month.

\begin{tabular}{|c|c|c|c|c|c|c|c|c|c|c|c|c|c|}
\hline \multirow[t]{2}{*}{ Organ } & \multicolumn{13}{|c|}{ Month } \\
\hline & Jan. & Feb. & Mar. & Apr. & May & June & July & Aug. & Sept. & Oct. & Nov. & Total & Percentage (\%) \\
\hline Liver & - & - & 1 & 2 & 2 & 5 & 16 & 18 & 5 & - & 1 & 50 & 33.8 \\
\hline Lungs & 5 & 2 & 2 & 1 & 1 & 4 & 3 & - & 1 & - & - & 19 & 12.8 \\
\hline Intestine & - & 2 & - & 1 & 2 & 3 & - & - & - & - & - & 8 & 5.4 \\
\hline Kidney & - & - & - & - & - & - & - & - & 2 & - & - & 2 & 1.3 \\
\hline Head & 3 & 13 & 8 & 3 & 7 & 11 & 2 & - & 6 & 7 & 5 & 65 & 43.9 \\
\hline Whole carcass & - & - & 1 & - & - & 1 & - & - & - & - & - & 2 & 1.3 \\
\hline Abomasum & - & 1 & - & - & - & - & - & - & - & - & - & 1 & 0.6 \\
\hline Total condemnation & - & 1 & - & - & - & - & - & - & - & - & - & 1 & 0.6 \\
\hline Total & 8 & 19 & 12 & 7 & 12 & 24 & 21 & 18 & 14 & 7 & 6 & 148 & 100 \\
\hline Percentage (\%) & 5.4 & 12.8 & 8.1 & 4.7 & 8.1 & 16.2 & 14.1 & 12.1 & 9.4 & 4.7 & 4.0 & 100 & - \\
\hline
\end{tabular}


TABLE 5: Summary of results of Kinyoun staining versus culture.

\begin{tabular}{lllllll}
\hline Organ & Number of samples & Kinyoun (+) & Kinyoun (-) & $\begin{array}{l}\text { Culture (+), } \\
\text { Kinyoun (-) }\end{array}$ & $\begin{array}{l}\text { Culture (-), } \\
\text { Kinyoun (+) }\end{array}$ & $\begin{array}{l}\text { Total Mycobacterium Percentage (\%) } \\
\text { bovis }\end{array}$ \\
\hline Lymph nodes & 31 & 22 & 9 & 2 & 4 & 17 \\
Lungs & 3 & 2 & 1 & 0 & 1 & 54.7 \\
Liver & 2 & 2 & 0 & 0 & 0 & 2 \\
\hline Total & $\mathbf{3 6}$ & $\mathbf{2 6}$ & $\mathbf{1 0}$ & $\mathbf{2}$ & $\mathbf{5}$ & $\mathbf{2}$ \\
\hline
\end{tabular}

using both routine meat inspection and confirmation by laboratory diagnosis of $M$. bovis. Kinyoun staining allowed the identification of AFB resistant to alcohol from $72.2 \%(26 / 36)$ of suspect samples. However, this technique proved inadequate for the presumptive diagnosis of bTB because it yielded many false negatives. This might be because of the nature of tuberculous lesions and their stage of evolution (Vestal 1975). The sensitivity of Kinyoun staining compared to culture was $91.3 \%$, while the specificity was $61.5 \%$. Biochemical tests were successful in identifying and characterising 21 isolates of mycobacteria as $M$. bovis but failed to characterise two atypical mycobacteria. The choice of staining as a method of presumptive diagnosis of bTB was motivated by its speed, simplicity, cost and value (Thorel 1997). Amongst 26 Kinyoun positive samples, five yielded negative cultures. This could be explained by the inactivation or death of mycobacteria during the process of decontamination before culture (Mahjoubi 2006). The fact that M. bovis was isolated from two Kinyoun negative samples by culture illustrates the sensitivity of this technique. Also, this could be ascribed to paucibacillary samples, to insufficient microscopic observation with fewer microscopic fields examined, or to the heterogeneity of the distribution of mycobacteria in the sample (Thorel 1997). Atypical mycobacteria were isolated from two (8.7\%) samples. This proportion is slightly high compared to $2.3 \%$ reported by L'Kassmi et al. (1998).

The study showed that the gross lesion prevalence of bTB was slightly higher in females $(1.4 \%)$ than in males $(0.6 \%)$. This could probably be ascribed to the stressful nature of the females' husbandry (housing and extended confinement); the stress of lactation and gestation make them more vulnerable to infection. In addition, contact with humans with TB during milking might be another reason (Imtiaz et al. 2008; Skuce, Allen \& McDowell 2011; Walter, Guilherme \& Leila 2007).

Animals older than 2 years had a higher gross lesion prevalence $(1.6 \%)$ than those younger than 2 years $(0.6 \%)$. Older cattle have had a longer overall exposure to tuberculosis, but calves can become infected in the uterus or by drinking milk from a tuberculous cow. This contradicts other reports (Blood, Henderson \& Radostitis 2000; Mohammed, Hailu \& Gebreyesus 2012) which indicated that young animals are less resistant than adults. Furthermore, as the current study was based on gross lesions, the bacteria might have been missed in the incubation stages in younger animals (Brooks-Pollock et al. 2013). The macroscopic lesions appear at advanced stages of infection (Awah-Ndukum et al. 2012; Imtiaz et al. 2008; Skuce et al. 2011).

The higher figure observed between June and August coincided with the dry season. During this time farmers are forced to sell all animals in poor body condition to reduce losses as a result of deaths and hence more animals presented for slaughter are likely to be infected.

Although the overall prevalence of bTB was $0.5 \%$ (which is not alarming in a large-scale study), the zoonotic status of the disease warrants implementation of appropriate control strategies. This prevalence is lower than the 1.33\%, 1.67\% and 2.12\% reported by El Abrak, Lhor and Zrira (2001) in Morocco in 1998, 1999 and 2000, respectively. However, this prevalence is higher than the $0.03 \%$ reported by Shitaye et al. (2006) in Ethiopia.

Limitations to this study include the lack of appropriate facilities to perform more sensitive and specific diagnostic methods, such as polymerase chain reaction (PCR) assay; a limited data collection period of only 11 months; and a sample limited to only culled animals.

\section{Conclusion}

The study findings indicate that routine meat inspection protocols utilised in Rwandan abattoirs are able to detect $0.9 \%$ of bTB lesions at the gross level. Laboratory culture and microscopic examination were demonstrated to improve the detection level as reference tests, even though they failed to detect a small number of carcasses that presented with grossly visible lesions of bTB. The findings of this study have managed to establish a baseline prevalence of bTB in Rwanda at $0.5 \%$. There is potential for further research to establish the true prevalence of bTB using high-sensitivity, high-specificity techniques such as PCR assay, performed over a longer period of time using randomly selected animals in the field rather than at an abattoir.

Given that many urban families in Kigali and other large cities keep some dairy animals in their backyards (and the trend is increasing), the human-animal interface continues to expand. The true prevalence of bTB and human TB must be determined as such information is of the utmost importance to city health authorities in order for surveillance and control measures to be applied accurately. The relationship between human TB and $\mathrm{BTB}$ at the human-animal interface in Rwanda can only be established if the true prevalence of both conditions is known. Finally, this study shows that bTB is an important cause of beef meat condemnation, leading to significant economic losses for farmers.

\section{Acknowledgements}

We thank Dr Anselme Achille Shyaka - because of his unconditional support, we were able to overcome the difficult 
times that we experienced during this study. Our thanks also go to Dr Louis Fischer for his advice and support, both materially and morally. We express our deep appreciation to the technicians of SABAN-Nyabugogo Abattoir and the laboratories of ISAE Busogo who assisted in sample collection and laboratory analysis, respectively.

\section{Competing interests}

The authors declare that they have no financial or personal relationship(s) which would have inappropriately influenced the writing of this article.

\section{Authors' contributions}

G.H. (University of Rwanda) was responsible for the fieldwork, prepared the samples and performed most of the experiments. J.R. (United States Centers for Disease Control and Prevention) was the supervisor and contributed to project design. M.O.N. (University of Nairobi) and B.M. (University of Fort Hare) contributed to the writing and editing of the manuscript.

\section{References}

Aranaz, A., De Juan, L., Montero, N., Sánchez, C., Galka, M., Delso, C. et al., 2004 'Bovine tuberculosis (Mycobacterium bovis) in wildlife in Spain', Journal of Clinical Microbiology 42(6), 2602-2608. http://dx.doi.org/10.1128/JCM.42.6.2602 2608.2004

Awah-Ndukum, J., Kudi, A.C., Bradley, G., Ane-Anyangwe, I., Titanji, V.P.K., Fon-Tebug, S. et al., 2012, 'Prevalence of bovine tuberculosis in cattle in the highlands of Cameroon based on the detection of lesions in slaughtered cattle and tuberculin skin tests of live cattle', Veterinarni Medicina 57(2), 59-76.

Ayele, W.Y., Neil, S.D., Zinsstag, J., Weiss, M.G. \& Pavlik, I., 2004, 'Bovine tuberculosis: An old disease but a new threat to Africa', International Journal of Tuberculosis and Lung Diseases 8, 924-927.

Biet, F., Boschiroli, L.M., Thorel, M.F. \& Guilloteau, L.A., 2004, 'Zoonotic aspects of Mycobacterium bovis and mycobacterium avium-intracellular complex (MAC)', Veterinary Research 36, 411-436. http://dx.doi.org/10.1051/vetres:2005001

Blood, D.C., Henderson, J.A. \& Radostitis, O.M., 2000, 'Diseases caused by bacteria', in O.M. Radostitis, C.G. Gay, D.C. Blood \& K.W. Hinchcliff (eds.), Veterinary medicine A textbook of the diseases of cattle, sheep, pigs, goats and horses, 9th edn., n.p., W.B. Saunders, London

Brooks-Pollock, E., Conlan, A.J.K., Mitchell, A.P., Blackwell, R., Trevelyan, J., McKinley, T.J. et al., 2013, 'Age-dependent patterns of bovine tuberculosis in cattle', Veterinary Research 44, 97. http://dx.doi.org/10.1186/1297-9716-44-97

Chantal, J., 2001, 'A propos de la tuberculose', Environnement et Santé Publique Vétérinaire, Numéro spécial: Tuberculose [About tuberculosis, Environment and Veterinary Public Health, Special issue: Tuberculosis], Bulletin de liaison de l'association Francophone pour l'étude des relations Environnement - Santé Publique Vétérinaire, École Nationale Vétérinaire de Toulouse, Toulouse.

Cosivi, O., Grange, J.M., Daborne, C.J., Raviglione, M.C., Fujikura, T., Cousins, D. et al., 1998, 'Zoonotic tuberculosis due to Mycobacterium bovis in developing countries', Emerging Infectious Diseases 4, 59-70. http://dx.doi.org/10.3201/ eid0401.980108
Cosivi, O., Meslen, F.X., Daborne, C.J. \& Grange, J.M., 1995, 'Epidemiology of Mycobacterium bovis in animals and humans, with particular reference to Africa', Revue Scientifique et Technique, Office Internationale des Epizooties 14, 733-746.

El Abrak, A., Lhor, Y. \& Zrira, A., 2001, 'Tuberculose bovine au Maroc: Situation épidémiologique et perspectives de lutte' [Bovine tuberculosis in Morocco: Epidemiological situation and prospects of fight], Bulletin d'Epidémiologie Vétérinaire 7, 1-2.

Franck, B., Boschiroli, M.L., Thorel, M.F. \& Guilloteau L.A., 2005, 'Zoonotic aspects of Mycobacterium bovis and Mycobacterium avium-intracellulare complex (MAC)', Veterinary Research 36, 411-436. http://dx.doi.org/10.1051/vetres:2005001

Haddad, N. \& Durand, B., 2001, 'Intérêt et limites des différentes techniques de caractérisation des isolats: Exemple de la tuberculose' [Interest and limitations of the various techniques for characterising isolates: Example of tuberculosis], Epidémiologie et Santé Animale 39, 43-59.

Imtiaz, A.K., Khan, A., Mubarak, A. \& Ali, S., 2008, 'Factors affecting prevalence of bovine tuberculosis in Nili Ravi buffaloes', Pakistan Veterinary Journal 28(4), 155-158.

Krauss, H., Weber, A., Appel, M., Enders, B., Isenberg, D.H., Schiefer, H.G. et al., 2003, Zoonoses: Infectious diseases transmissible from animals to humans, 3rd edn. ASM Press, Washington D.C.

L'Kassmi, H., Oualine, M., Baaj, A. \& Nejmi, S., 1998, 'Essai d'identification des mycobactéries: A propos de 214 souches' [Trial of mycobacteria identification: About 214 strains], Revue Marine de Biologie et Infectiologie 4(1), 39-47.

Mahjoubi, W., 2006, 'Identification of Mycobacteria', presentation made at the Microbiology Laboratory, Abderrahmen Mami Hospital, Ariana, Tunisia on 31 March 2006, viewed 13 April 2011, from http://www.defra.gov.uk/animalh/publichealth/ otm/review/index.html

Michel, A.L., 2002, 'Implications of tuberculosis in African wildlife and livestock', Annals of the New York Academy of Sciences 969, 251-255. http://dx.doi. org/10.1111/j.1749-6632.2002.tb04387.x

Michel, A.L., De Klerk, L.-M., Van Pittius, N.C.G., Warren, R.M. \& Van Helden, D.P., 2007, 'Bovine tuberculosis in African buffaloes: Observations regarding Mycobacterium bovis shedding into water and exposure to environmental mycobacteria', $B M C$ Veterinary Research (3), 23. http://dx.doi.org/10.1186/1746-6148-3-23

Minisante, 2007, Annual Report 2007, Ministry of Health, Kigali.

Mohammed, N., Hailu, M. \& Gebreyesus, M., 2012, 'Prevalence and zoonotic implications of bovine tuberculosis in Northwest Ethiopia', International Journal of Medicine and Medical Sciences 2(9), 188-192.

Nolte, F. \& Metchock, B., 1995, 'Mycobacterium', in P.R. Murray, E.J. Baron, M.A. Pfaller, F.C. Tenover \& R.H. Yolken (eds), Manual of clinical microbiology, 6th edn., pp. 400-437, American Society for Microbiology, Washington, D.C.

OIE, 2009, Manual of diagnostic tests and vaccines for terrestrial animals: Bovine tuberculosis, World Organisation for Animal Health, Paris.

OIE, 2012, Bovine tuberculosis, viewed 07 January 2014, from http://www.oie.int/ fileadmin/Home/eng/Media_Center/docs/pdf/Disease_cards/BOVINE-TB-EN.pdf

Palmer, M.V., Waters, W.R. \& Whipple, D.L., 2004, 'Investigation of the transmission of Mycobacterium bovis from deer to cattle through indirect contact', American Journal of Veterinary Research 65(11), 1483-1489. http://dx.doi.org/10.2460/ ajvr.2004.65.1483

Shitaye, J.E., Getahun, B., Alemayehu, T., Skoric, M., Treml, F., Fictum, P. et al., 2006 , 'A prevalence study of bovine tuberculosis by using abattoir meat inspection and tuberculin skin testing data, histopathological and IS6110 PCR examination of tubsues with tuberculous lesions in cattle in Ethiopia', Veterinarni Medicina 51(11) 512-522.

Skuce, R.A., Allen, A.R. \& McDowell, S.W.J., 2011, Bovine tuberculosis (TB): A review of cattle-to-cattle transmission, risk factors and susceptibility, Agri-food and Biosciences Institute, Belfast.

Thorel, M.F., 1997, 'Isolement et identification des Mycobactéries: Mycobacterium bovis et Mycobacterium paratuberculosis', in J. Berrada, M. Bouslikhane \& N. Bouchriti (eds.), Proceedings of the Second International Conference on Animal Tuberculosis in Africa and the Middle East, Rabat, Morocco, October 04-06, 1995, pp. 67-80.

Vestal, B.S., 1975, Procedures for the isolation and identification of mycobacteria, 3rd edn., Centers for Disease Control and Prevention, Atlanta, Georgia.

Walter, L., Guilherme, N.S. \& Leila, S.F., 2007, 'Management factors associated with bovine tuberculosis on dairy herds in Rio de Janeiro, Brazil', Revista Brasileira de Ciência Veterinária 14(2), 98-100. 